\title{
Persistence of Natural Killer (NK) cell lymphocytosis with hyposplenism without development of leukaemia Sujoy Khan ${ }^{1,2}$ and K Myers*1
}

Address: ${ }^{1}$ Department of Haematology, Prince Charles Hospital, Merthyr Tydfil, Wales, CF47 9DT UK and ${ }^{2}$ Department of Immunopathology, St. Bartholomew's Hospital, 51-53 Bartholomew's Close, West Smithfield, London, EC1A 7BE UK

Email: Sujoy Khan - sujoykhan@aol.com; K Myers* - kajcmyers@aol.com

* Corresponding author

Published: 07 September 2005

BMC Clinical Pathology 2005, 5:8 doi:10.1 186/1472-6890-5-8

This article is available from: http://www.biomedcentral.com/I472-6890/5/8

(c) 2005 Khan and Myers; licensee BioMed Central Ltd.

This is an Open Access article distributed under the terms of the Creative Commons Attribution License (http://creativecommons.org/licenses/by/2.0), which permits unrestricted use, distribution, and reproduction in any medium, provided the original work is properly cited.

\begin{abstract}
Background: Natural killer (NK) cell lymphocytosis usually has an indolent course and can progress into massive lymphocytosis with development of cytopenias and neoplastic diseases. NKcells usually express one or more "NK-associated" antigens (CDI6, CD56, CD57). Reactive expansions are seen in autoimmune diseases, viral infections, solid tumours and non-Hodgkin's lymphoma.
\end{abstract}

Case presentation: We report a lady with a benign clinical course over 10 years and persistent CD8+/CD3-/CD57+/CDI6+ LGL proliferation with presence of Howell-jolly bodies (functional hyposplenism), an association not previously described.

Conclusion: We discuss the possible causes of clonal expansion and conclude that this may be part of the spectrum of immune dysregulation associated with NK-cell lymphocytosis.

\section{Background}

The lymphoproliferative disease of granular lymphocytes (LDGL) results from the chronic proliferation of large granular lymphocytes (LGL) that may result from antigenic stimulation ${ }^{1,2}$. Natural Killer (NK) cells constitute approximately $15 \%$ of the peripheral blood mononuclear cell fraction. NK cells lack both CD3 and T-cell receptor expression, majority express CD56 and/or CD16 $\left(\mathrm{F}_{\mathrm{c} \gamma}\right.$ receptor). Granular lymphocytosis greater than $2,000 / \mu \mathrm{L}$ lasting for more than 6 months is regarded as the criteria to define the disease $[1,2]$. Patients with chronic, indolent NK lymphocytosis may develop cytopenias, splenomegaly, vasculitic skin lesions, and peripheral neuropathy [3]. We discuss a unique case of chronic, indolent NK lymphocytosis who presented with severe hyposplenism and has not developed leukaemia over a decade.

\section{Case presentation}

A 46-year-old lady was referred to the haematology clinic for evaluation of lymphocytosis in May 1993. She had severe lethargy and intermittent right upper abdominal discomfort without any significant loss in weight. Her past medical history included essential hypertension controlled on atenolol $100 \mathrm{mg}$ once daily and was also on frusemide $40 \mathrm{mg}$ once daily. She had no significant surgical history other than having undergone cholecystectomy in 1972. She had never smoked nor consumed alcohol. Physical examination showed no evidence of lymphadenopathy. Complete blood count showed normal haemoglobin concentration $14.8 \mathrm{~g} / \mathrm{dl}$, macrocytosis (MCV 100.1), raised white cell count at $13.4 \times 10^{9} / \mathrm{L}$, lymphocytosis (absolute number $6.3 \times 10^{9} / \mathrm{L}$ ), and normal neutrophil count (absolute number $5.6 \times 10^{9} / \mathrm{L}$ ). Peripheral blood showed numerous Howell-Jolly bodies within 
erythrocytes. Thyroid function tests, protein electrophoresis, C-reactive protein, immunoglobulin levels and autoimmune screening were normal. Ultrasonography and computed tomography scan of the abdomen and pelvis did not reveal retroperitoneal or mediastinal lymphadenopathy, but the spleen was noted to be very atrophic. Gastroscopy showed multiple gastric erosions and the initial impression was of celiac disease complicated by lymphoma and lymphocytosis.

Duodenal biopsy showed well-formed villi and no increase in intraepithelial lymphocytes thereby excluding celiac disease. Colonoscopy and barium studies were normal. She was clinically diagnosed to have functional hyposplenism, considering the presence of Howell-Jolly bodies, and was given hemophilus influenzae $(\mathrm{HiB})$ vaccine, pneumovax vaccine and counselled for long term oral Penicillin V. In November 1994, another complete blood count showed a white cell count of $15.3 \times 10^{9} / \mathrm{L}$ with absolute number of lymphocytes of $6.6 \times 10^{9} / \mathrm{L}$. Bone marrow biopsy showed 25\% infiltration with large granular lymphocytes. Peripheral blood smear revealed that the majority of lymphocytes had atypical morphology with large atypical nuclei and abundant cytoplasm containing fine azurophilic granules. Immunophenotyping showed CD16+/CD3- cells which were mainly reactive and another clonal cells which were CD57+/CD8+ suggesting NK-LGL (Natural Killer-Large Granular Lymphocyte) activity. $80 \%$ CD3 + cells were $\alpha / \beta$ and $20 \% \gamma / \delta$ and a clonal population of CD16+/CD56+ cells.

She presented in March 1995 with lethargy and diffuse enlargement of her thyroid gland. Lymphocytosis persisted (WBC $15.7 \times 10^{9} / \mathrm{L}$, absolute lymphocyte count 8.2 $\times 10^{9} / \mathrm{L}$ ), antimicrosomal antibody was positive at a titre of 1:6400, anti thyroglobulin antibody was positive at 1:1280 but thyroid function tests (TSH 1.69, $\mathrm{fT}_{4} 13.0$ ) and isotope thyroid scan $\mathrm{I}^{123}$ were normal. Immunoglobulins, C3, C4 and C-reactive protein levels were normal. There was spontaneous regression of her thyroid swelling by December 1996 at which time antimicrosomal antibody was negative. Follow-up for 10 years showed the persistence of lymphocytosis (February 2004-WBC $12.5 \times 10^{9} / \mathrm{L}$, absolute lymphocyte count $5.4 \times 10^{9} / \mathrm{L}$ ) without development of autoimmune disease, autoantibodies, neutropenia or infections.

\section{Conclusion}

This is the first report of the unusual occurrence of Howell-Jolly bodies in a patient with persistent NK-LGL lymphocytosis. She did not develop autoimmune disease, neutropenic infections or vasculitic syndromes but the lymphocytosis persisted.
Cytogenetic, molecular analyses and monoclonal antibodies (MoAbs) both against the V-gene regions of the Tcell receptor (TCR) and the molecules of the p58 family on NK cells [4] are used to characterize the expanded cells. Polyclonal proliferation may represent a preneoplastic condition, since there is some evidence that suggests that it is probably a multistep process [5]. In such cases, the clonal expansion might evolve from the abnormal immunoregulation of a response to inciting antigens, for example, viruses [5].

The Yorkshire Leukaemia Group investigated 870 adults with 'persistent' LGL/NKa ${ }^{+}$(Large Granular Lymphocyte/ Natural Killer associated) expansions suggest that clonal expansions may be more frequent than reported and found high proportion with persistent neutropenia and all patients with $\mathrm{CD} 8+\mathrm{NKa}+$ abnormalities had rearranged TCR genes [6]. Splenomegaly has been reported in $19 \%$ in a case series of 68 patients with clonal T-LGL proliferations [7], but uniquely, in our case, the lymphocytosis has remained stable and Howell-Jolly bodies were observed. The presence of Howell-Jolly bodies and liverspleen scintigraphy showing absence of spleen is considered diagnostic of functional hyposplenia [8]. An autoimmune mechanism seems probable but not certain [9].

Clonality does not imply malignancy. It has been detected during autoimmune processes, including rheumatoid arthritis, and in bone marrow transplantation recipients [9]. Clonal populations in such cases most likely represent epiphenomenon of an immunoregulatory disorder. There is evidence of persistent CD8+ clonal expansions in normal elderly individuals $[10]$ and clonal V-alpha $12.1^{+} \mathrm{T}$ cell expansions in uncomplicated rheumatoid arthritis [11] that could mean that these proliferations are benign.

In summary, our lady with persistent NK cell lymphocytosis and hyposplenism had a benign clinical course over a decade. We report this case as presence of Howell-Jolly bodies has not been previously reported and postulate that the hyposplenism is probably a part of the spectrum of immune dysregulation associated with NK-LGL.

\section{Abbreviations}

LGL-large granular lymphocytes; NK-Natural Killer; TCRT-cell receptor.

\section{Competing interests}

The author(s) declare that they have no competing interests.

\section{Authors' contributions}

SK drafted the initial manuscript. KM made changes to the manuscript and as corresponding author had full access to 
all data and was responsible for the decision to submit for publication.

\section{References}

I. Epling-Burnette PK, Bai F, Wei S, Chaurasia P, Painter JS, Olashaw N, Hamilton A, Sebti S, Djeu JY, Loughran TP: ERK couples chronic survival of NK cells to constitutively activated Ras in lymphoproliferative disease of granular lymphocytes (LDGL). Oncogene 2004, 23(57):9220-9.

2. Lamy T, Loughran TP Jr: Clinical features of large granular lymphocyte leukemia. Semin Hematol 2003, 40(3): I85-95.

3. Tefferi A, Li CY, Witzig TE, Dhodapkar MV, Okuno SH, Phyliky RL: Chronic natural killer cell lymphocytosis: a descriptive clinical study. Blood 1994, 84(8):272l-5.

4. Moretta L, Ciccone E, Mingari MC, Biassoni R, Moretta A: Human natural killer cells: Origin, clonality, specificity, and receptors. Adv Immunol 1994, 55:34 I-80.

5. Zambello R, Loughran TP Jr, Trentin L, Pontisso P, Battistella L, Raimondi R, Facco M, Sancetta R, Agostini C, Pizzolo G: Serological and molecular evidence for a possible pathogenetic role of viral infection in CD3-negative NK-type lymphoproliferative disease of granular lymphocytes. Leukemia I995, 9(7): I 207-I I.

6. Scott CS, Richards SJ, Sivakumaran M, Short M, Child JA, Hunt KM, McEvoy M, Steed AJ, Balfour IC, Parapia LA: Transient and persistent expansions of large granular lymohocytes (LGL) and NKassociated (NKa) cells: the Yorkshire Leukaemia Group Study. Br J Haematol 1993, 83:505-5I5.

7. Dhodapkar MV, Li CY, Lust JA, Tefferi A, Phyliky RL: Clinical Spectrum Of Clonal Proliferations of T-Large Granular Lymphocytes: A T-Cell Clonopathy of Undetermined Significance? Blood 1994, 84(5): 1620-7.

8. Christian Görg, Miriam Eichkorn, Gerhard Zugmaier: The small spleen: Sonographic patterns of functional hyposplenia or asplenia. Journal of Clinical Ultrasound 2003, 3 I (3): I 52-I 55.

9. Wardrop CA, Dagg JH, Lee FD, Singh H, Dyet JF, Moffat A: Immunological abnormalities in splenic atrophy. Lancet 1975, 2(7923):4-7. 1975 Jul 5

10. Posnett DN, Sinha R, Kabak S, Russo C: Clonal populations of $\mathbf{T}$ cells in normal ederly humans: The $T$ cell equivalent to "benign monoclonal gammopathy.". J Exp Med 1994, I 79:609. (published erratum appears in J Exp Med I79:1077, 1994)

II. DerSimonian H, Sugita M, Glass DN, Maier AL, Weinblatt ME, Reme $\mathrm{T}$, Brenner MB: Clonal V-alpha $12.1^{+} \mathrm{T}$-cell expansions in peripheral blood of rheumatoid arthritis patients. J Exp Med 1993, I 77: I623.

\section{Pre-publication history}

The pre-publication history for this paper can be accessed here:

http://www.biomedcentral.com/1472-6890/5/8/prepub

\section{Publish with Biomed Central and every scientist can read your work free of charge}

"BioMed Central will be the most significant development for disseminating the results of biomedical research in our lifetime. "

Sir Paul Nurse, Cancer Research UK

Your research papers will be:

- available free of charge to the entire biomedical community

- peer reviewed and published immediately upon acceptance

- cited in PubMed and archived on PubMed Central

- yours - you keep the copyright 